\title{
THE ARCHITECTURAL INFORMATION SYSTEM SIARCH3D-UNIVAQ FOR ANALYSIS AND PRESERVATION OF ARCHITECTURAL HERITAGE
}

\author{
M. Centofanti, R. Continenza, S. Brusaporci, I. Trizio \\ Department of Architecture and Urban Planning - University of L'Aquila \\ mario.centofanti@univaq.it, romolo.continenza@univaq.it, stefano.brusaporci@univaq.it, ilaria.trizio@libero.it
}

Commission V, WG 4

KEY WORDS: Architectonical Informative Systems, 3D modelling, Architectonical surveying.

\begin{abstract}
:
The research group of L'Aquila University defined a procedure to create an architectonical Information System called SIArchUnivaq. This information system can be integrated with "Risk Map" Italian database. The SIArch-Univaq is based on importation of architectonical three-dimensional photorealistic models in GIS environment. 3D models are realised according to building constructive elements, derived by a critical architectonic surveying; the importation of models into GIS allows the interrogation of the constructive elements (i.e. beam, window, door, etc.): this favour the knowledge of the architectonical heritage, indispensable requirement to plan processes of restoration, maintenance and management.
\end{abstract}

\section{INTRODUCTION}

During the Research of National Interest MIUR PRIN COFIN 2006, principal investigator Prof. Mario Centofanti, the research unit of L'Aquila University studied a procedure to build an Architectonical Information system SIArch-Univaq (Centofanti et alli, 2008; Brusaporci, 2010); this procedure integrates architectonical 3D digital models, if truthlikeness, with different kind of digital data into GIS software. The critical definition of 3D models according to constructive components let the interrogation of the whole models and of single components.

In this contribute we present the results obtained developing and probing the study, with the implementation into SIArchUnivaq of buildings with different typological, architectonical, spatial, geometric-dimensional, historical, figurative, technological-constructive and degradation characteristics. The SIArch-Univaq has important and immediate application in documentation historical architectonic heritage, characterised by important stratification and modification phenomena; further the research on SIArch-Univaq focus on project processes and building yard steps, for its useful application in restoration, in yard monitoring, last but not least in planning maintenance instalment.

\section{ARCHITECTURAL INFORMATIVE SYSTEM}

Essential methodological condition for planning preservation, conservation and fruition operations on architectonical heritage is the availability of extensive and accessible documentation.

For example, it's not simple integrate documentary and archival information with geometrical-dimensional data and moreover with technological systems and degradation processes information.

To realise an exhaustive architectonical information system useful for different applications, the experience suggests to use only one digital meta-model to manage different kind of data graphical, photographical, multimedia and alphanumerical -, above all in case of cultural and architectonical heritage restorations or risk and vulnerability valuation.

The research's result has been favoured by quick diffusion of GIS software, also in different subject areas from geographical ones where it's usually applied. The numerous experiences in territorial, archaeological and architectonical areas tested GIS application, above all when information and spatial analysis are used in a bi-dimensional way; recently GIS is ever more used for cultural and architectonic heritage documentation (Trizio, 2007. Clini, 2007. Cundari, 2007. Trizio, 2009). Nevertheless the three-dimensional consistence of architecture, distinctive feature of this discipline, has proposed new problems to information systems users and software houses.

Aim of this research is using the information instrument to collect, analyse and easily questioning the large quantity of data related to historical architectonical heritage. Then it's defined a database referred to the spatial dimension of architecture, that can integrate alphanumerical, raster and vectorial information, and that can generate up-to-date synthesis report. To reach this aim it's necessary define a geo-referenced information system integrated to digital three-dimensional architectonical models.

Focusing on historical architecture, we consider building information modelling oriented software not presently suitable, because they are not friendly in order to architectonical surveying questions: they are constitutively organised according to pre-defined objects libraries, antithetic condition to the generic characteristics of historical buildings. So we preferred study the integration into GIS of different kinds of 3D models, built with several surveying modalities, for example MESH or NURBS surfaces derived by point clouds.

\section{DATA BASE FOR ARCHITECTONICAL GIS}

For an architectonic information system, database information are: building's location and identification (geo-referencing, land registry identification, use, change of properties, etc.), historical events (historical archival documents, tests, chronicles, iconographies, etc.), geometric characteristics (morphology, topological aspects, metrical data, etc.), constructive building 
technologies (materials, structures, systems, etc.), conservation conditions (structural problems, instability and pathologies, etc.), diagnostic campaigns (on terrain, structure, technological system, finish and decorative elements, etc.), kind and number of restoration, conservation and maintenance intervention (Continenza, 2010).

In particular information that can be integrated into the architectonic information system are:

- alphanumerical data on characteristics, propriety and constitution (i.e. localization, kind of uses, conservation, etc.);

- alphanumerical historical documents (files, transcriptions, etc,);

- raster historical documents (maps, iconographies, various kinds of imagines, etc.);

- surveying alphanumerical data (quantities, materials, constructive techniques, degradation, etc.);

- surveying vectorial geo-referenced data;

- surveying raster data (photograph, orthophotograph, etc.);

- alphanumerical diagnostics data;

- raster diagnostics data;

- vectorial documentation of interventions occurred in the past;

- raster data of interventions occurred in the past.

The required functionalities are defined according to architectonical information system users' necessities; the more important are:

- 2D and 3D vectorial visualization of architectonical complex at suitable scales;

- individuation and quantification of areas referred to specific themes;

- interrogation of database schedule according to specific themes;

- calculation of quantities to plan interventions;

- technical economic valuation for planning hypothesis;

- visualization of photographs and documents;
- generation of summary evaluative schedules;

- definition of hypothesis for virtual restoration;

- data exportation for restoration planning;

- data exportation for critical historical studies.

Qualifying element of SIArch architectonical information system is that its data can be integrated with Italian "Risk Map"; the cognitive schedules have been adapted to the ones used by ISCR - Istituto Superiore per la Conservazione e il Restauro (Institute for the Conservation and Restoration) for monumental heritage: the schedules use the same vocabulary and the same articulation in different analysis levels. Accordingly to ISCR ones, the building is disarranged in subsequent modules, corresponding to different levels of study:

- 'building complex': all the functional and formal elements constituted in an independent architectonical organism;

- 'building': each building identifiable into the complex;

- 'single room': minimal unit, usually corresponding to a single space.

Into the 'single room' each constructive component is characterized and classified.

\section{D MODELS IN GIS ENVIRONMENT FOR DATA SUPPORT, ORGANIZATION AND INTERROGATION}

To make more comprehensive and operable database structure, the interrogation and exportation data steps reflect the ones of input data. To aim this result the information system structure is planned referring to a three-dimensional model, as 3D is the main feature of architecture.

The modelling tools of GIS software only permit the construction of simple elements. So three-dimensional architectonic models are realised using most common 3D modelling software (Autodesk AutoCAD and 3D Studio Max, Robert McNell \& Associates Rhinoceros, INUS Technology

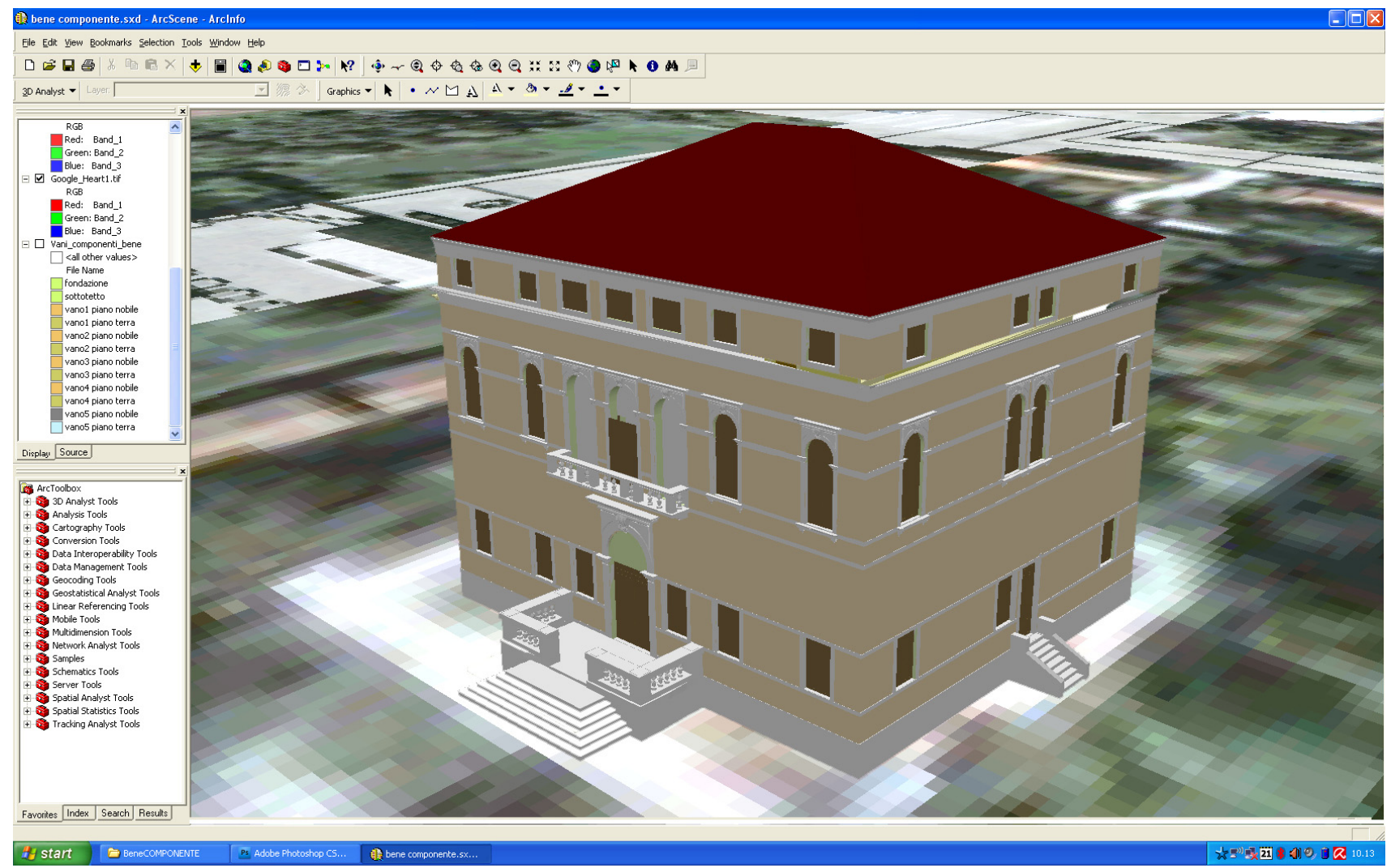

Picture 1 -3D model of Correr-Dolfin villa (PN, Italy) imported in ESRI software (ArcScene) 
Rapidform XOR), preserving the spatial references essential to the definition of a geo-referenced database to which information have to be connected. Then these model are imported into the architectonical information system. The number and the morphology of elements that have to be interrogated influence the level of detail and modalities of construction: for example if we want integrate into the model data of constructive elements (for example a particular of the technological system), we have to define a model with a consequent level of detail that allows the input, and the consequent output interrogation, of formal, metric and geometric characteristics (length, surfaces, volumes, materials, etc.), useful data to prefigure technical and economic planning. The architectonical information system integrated to 3D models first of all allows an easy visualization and exploration of the model, at all programmed levels of detail; than the 3D model can be used as inquiring support for the information system: interrogating any element, at required scale, user can be informed, for example, about material, age of construction, documentation on maintenance or restoration, can visualise historical images and diagnostic reports: quickly, efficiently and in an interactive way the user can consult the whole documentation.

Other functionalities permit recapitulation elaborations, such as, for example, the assessment of quantities for a peculiar work, parametric technical economic valuations, analysis for planning interventions. Thanks to modalities of visualization and printing is possible select and coordinate categories of data to generate report and synthesis elaborations, according to user's necessity. Other application of the architectonical information system are, for example, visualization of photography and documents or diachronic steps of specific thematic characters; the exportation of tests to favour critical historical studies.

\section{SOFTWARE AND PROCEDURES}

To realise the architectonical information system the research unit used ESRI ArcView suite, because this platform is widely tested and diffused, as by professionals as by public authorityes. From ArcScene of ArcGis 9.3 suite, ESRI GIS permits the importation of 3D models, built according to the described modalities, into a Multi Patch feature: that is a complex structure of the software that can visualize the model maintaining the original morphology and aspect assigned by modelling software.

The methodology for planning SIArch3D-Univaq has required, as first step, the adaptation of monumental heritage cognitive schedules of ISCR, used for the "Risk Map of Cultural Heritage", to the information system requirement. Lexicon, vocabulary and, above all, subdivision in different levels of study are the same. At levels of study corresponds the following schedule: first level '01_SIArch - Building complex; second level '02_SIArch - Single building'; third level '03_SIArch Single room'. Into this last level the studied components are: elevation structures, horizontal structures, vertical connection, internal surfaces and decorations, external surfaces and decorations, fixtures.

With regard to the schedule organization, the dataset of architectonical information system is planned, using ESRi ArcView suite to manage geographical data, organized in shape file, and Microsoft MS Access for relational database features.

The procedure for 3D complex models importation into ESRI GIS is the following: select 'Import 3D files' in 'From File', and the instrument 'Conversion' of 'ArcToolbox' allows the introduction into GIS of three-dimensional model from 3D Studio Max, Sketchup, VRML and OpenFlight (*.3ds, *.skp, *.wrl, *.flt); the name of the feature that is created into a new

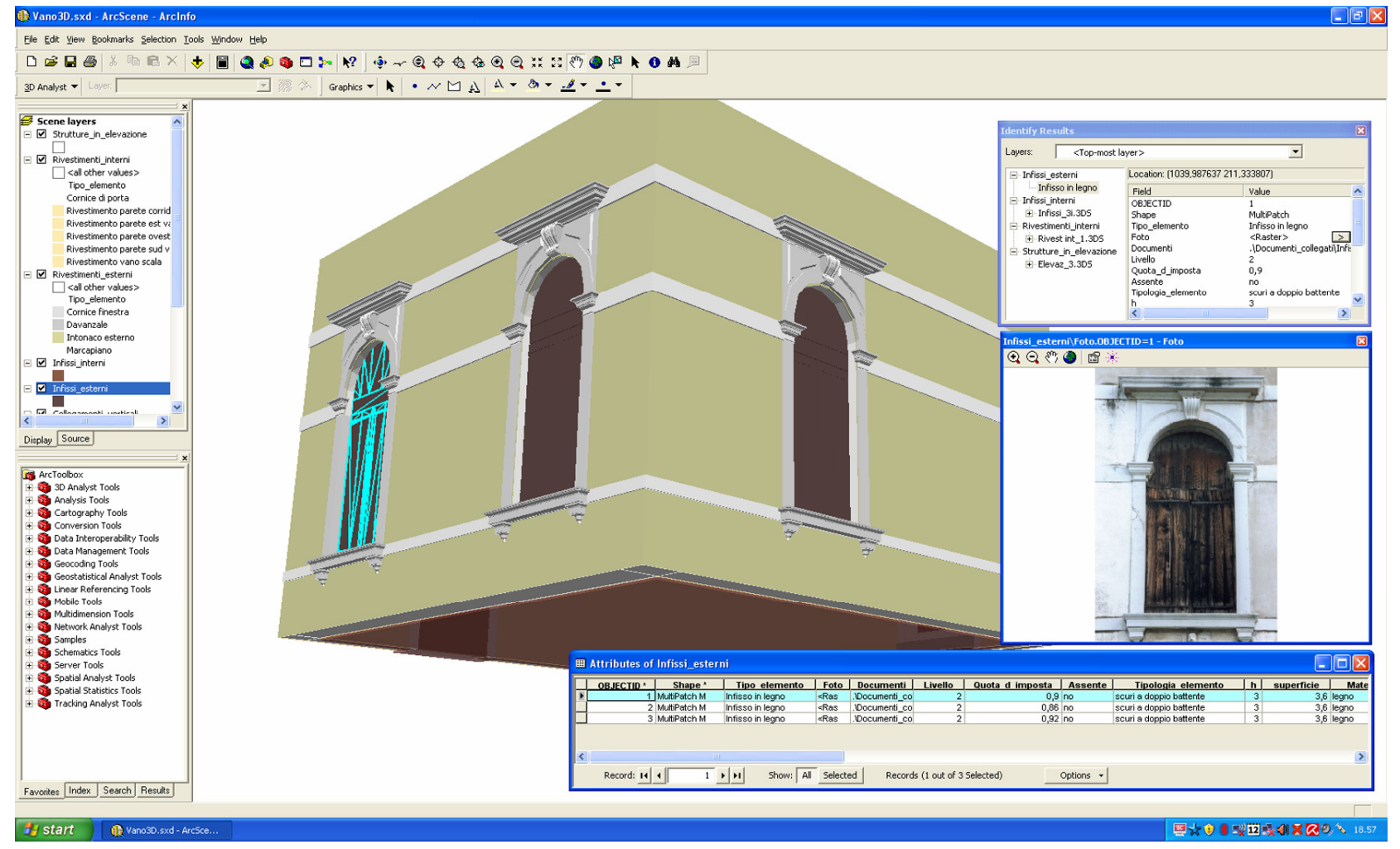

Picture 2 - Querying of an external architectural constructive element in GIS environment (Correr-Dolfin villa) 
Personal Geodatabase is required in the line 'Output MultiPatch Feature Class'. Now is possible finish the importing procedure and visualize the $3 \mathrm{~d}$ element.

The 3D element imported into ArcScene is similar to any other feature class - that can be visualised by direct inquiring ('Identify Results' window) or by the attributes schedule -, so preserves its dimensional and topological characters (georeferencing), and conserve the texturing applied by modelling software. Its graphical aspect can be modified.

With this procedure, the SIArch3D-Univaq allows to visualize and directly inquire on a 3D model the elements of three levels schedules, connected each other by hyperlinks.

\section{CASE STUDIES}

The first case study used to test the architectonical information system is Correr-Dolfin Villa in Roraipiccolo village (PN, Italy) (Trizio, 2010). In relation with its typology, this building is appropriate to be studied using the articulation in 'Building complex', 'Single building', 'Single room' of SIArch-Univaq. The villa is in the middle of a lot with important outbuildings (two 'barchesse', a botanic park, a chapel, rearward lakes, entrance parterre), has a Palladian organization, symmetric to orthogonal axes and with two floors. The 3D model realised with Autodesk AutoCAD 2008 was imported into ESRI GIS according to the definite procedure: the SIArch-Univaq allows to analyse the geo-referenced building, according as different scalar disaggregation, from level one 'Building complex' to level two 'Single building' and to level three 'Single room'. This last one can be divided in 'component elements' (for example door, windows, walls, etc.).

The second case study is the S. Paolo church in Peltuinum (AQ, Italy) (Brusaporci, Trizio, 2010). The church is isolated in the land near an archaeological park. The building has surveyed using Eos Systems PhotoModeler Scanner 6 digital photogrammetric software and laser scanner FARO/CAM 2 LS $840 / 88$. The building photorealistic mesh surface and the building 3D model, textured with Autodesk 3DStudioMax 2010, have been imported into ESRI ArcScene, that created a MultiPatch feature for each architectonical imported component, conserving spatial references for geodatabase system; all the information of the 'single room' level are referred to the geodatabase. ArcScene allows to texture also vertical surfaces into ESRI software.

The typological differences between a complex villa and an isolated church have suggested different methodologies to SIArch dataset planning: three levels of study have been used for the villa, whereas only one for the church. In fact the church do not belong to an architectonical complex, so cannot be considered as a 'Single building' of the complex; then the church, that has only one nave, can be analysed as a "Single room': the building has only one spatial unit, that can be disarranged in component elements. Whereas in analogy with the villa the analyzed components are: elevation structures, horizontal structures, vertical connections, internal surfaces and decorations, external surfaces and decorations, fixtures.

Other case study is the church of S. Maria del Carmine in Penne (PE, Italy). The church is not isolated but located in an historical urban centre. In particular the SIArch-Univaq have been tested during two phases of restoration and consolidation: the first one before the earthquake of 2009 , and the second one following the seismic event. The architectonical information system have been useful for a yard works topologically recording.

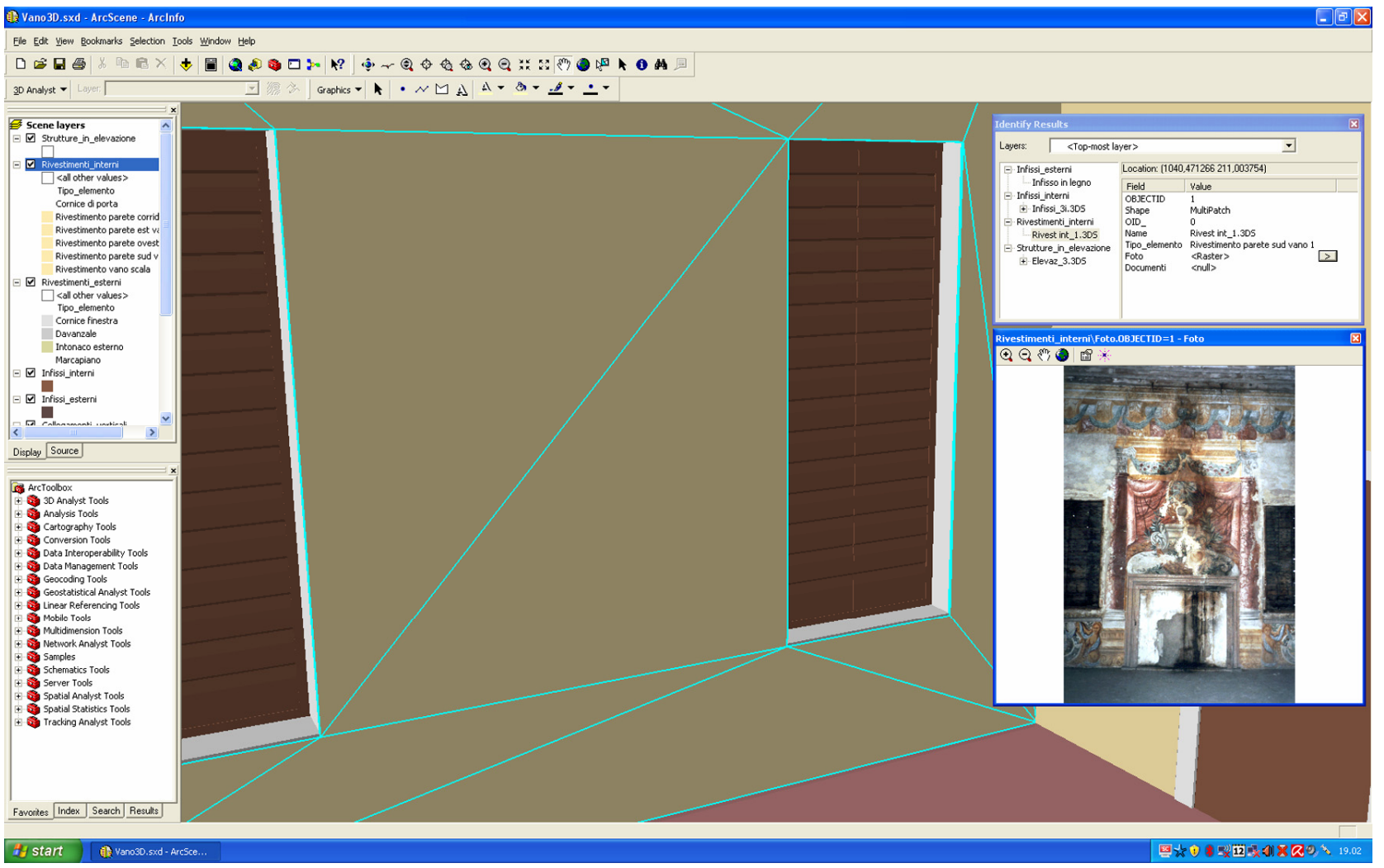

Picture 3 - Querying of an internal architectural constructive element in GIS environment (Correr-Dolfin villa) 

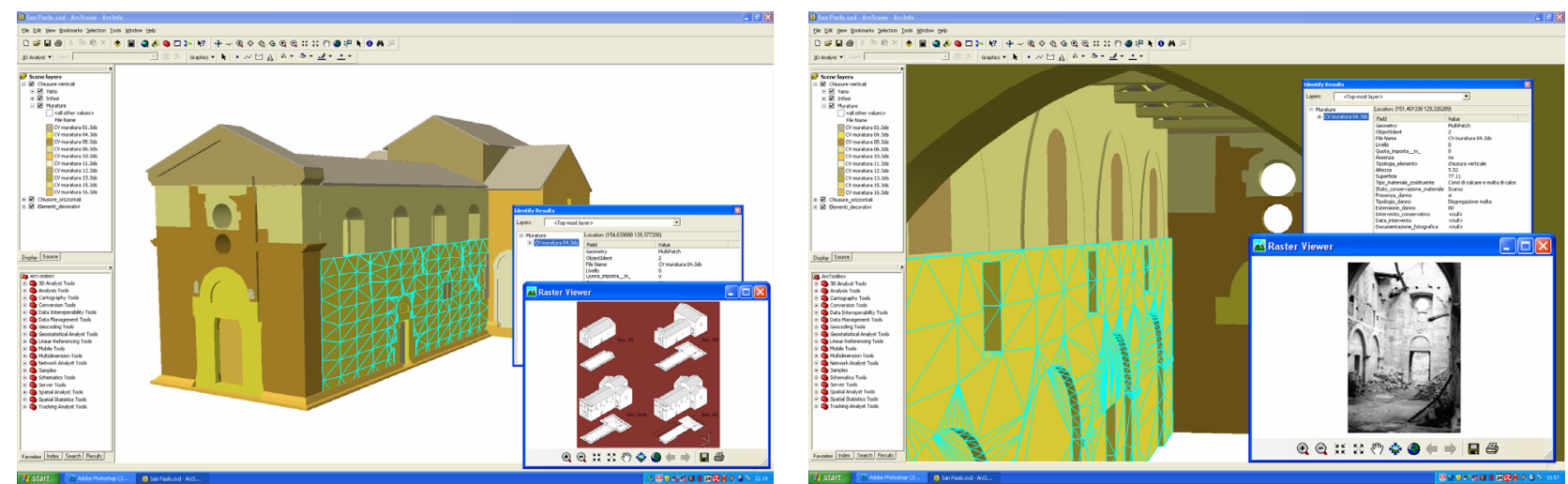

Pictures 4, 5 - Querying of 3D model of the S. Paolo church (AQ, Italy) in GIS environment.

\section{CONCLUSIONS}

Starting from a targeted elaboration of cognitive schedules of ISCR - Institute for the Conservation and Restoration, the SIArch-Univaq system favours processes of building knowledge, essential assumption for its restoration, maintenance and management. To obtain this result the research unit has planned a complex interactive database system for a systematic recording and integration of all the architectonical heritage information. The heterogeneity of system's data, at the beginning made the study difficult but, at least, made more interesting the results. In fact the architectonical information system is structured to integrate both historical artistic information, for example deduced by archival and iconographic documents, both surveying, scientific, technical and specialist data. The result is an instrument that can describe the architectonic heritage at the same time from several aspects in the more exhaustive way. The procedure offers an interactive system support for planning and building, according to the possibility of inquiring and individuating relationships between $3 \mathrm{D}$ models and information. At the same time the informative system consents to the researcher an accurate data reference.

This architectonical information system based on a 3D model, simplifies thematic analysis and synthetic elaborations: for example in case of restoration the realization of thematic maps or cartographies, individuation and quantification of volumes and areas characterized by specific themes, interrogation of database schedules according to quantity of characteristics, calculation of quantities for categories of intervention, technical-economic valuations for planning, virtual restoration hypothesis, last but not least exportation and plotting of elaborations. About building yard, and in particular restoration yard, the SIArch3D-Univaq consents time after time the definition of an up-to-date database. And it's very important in

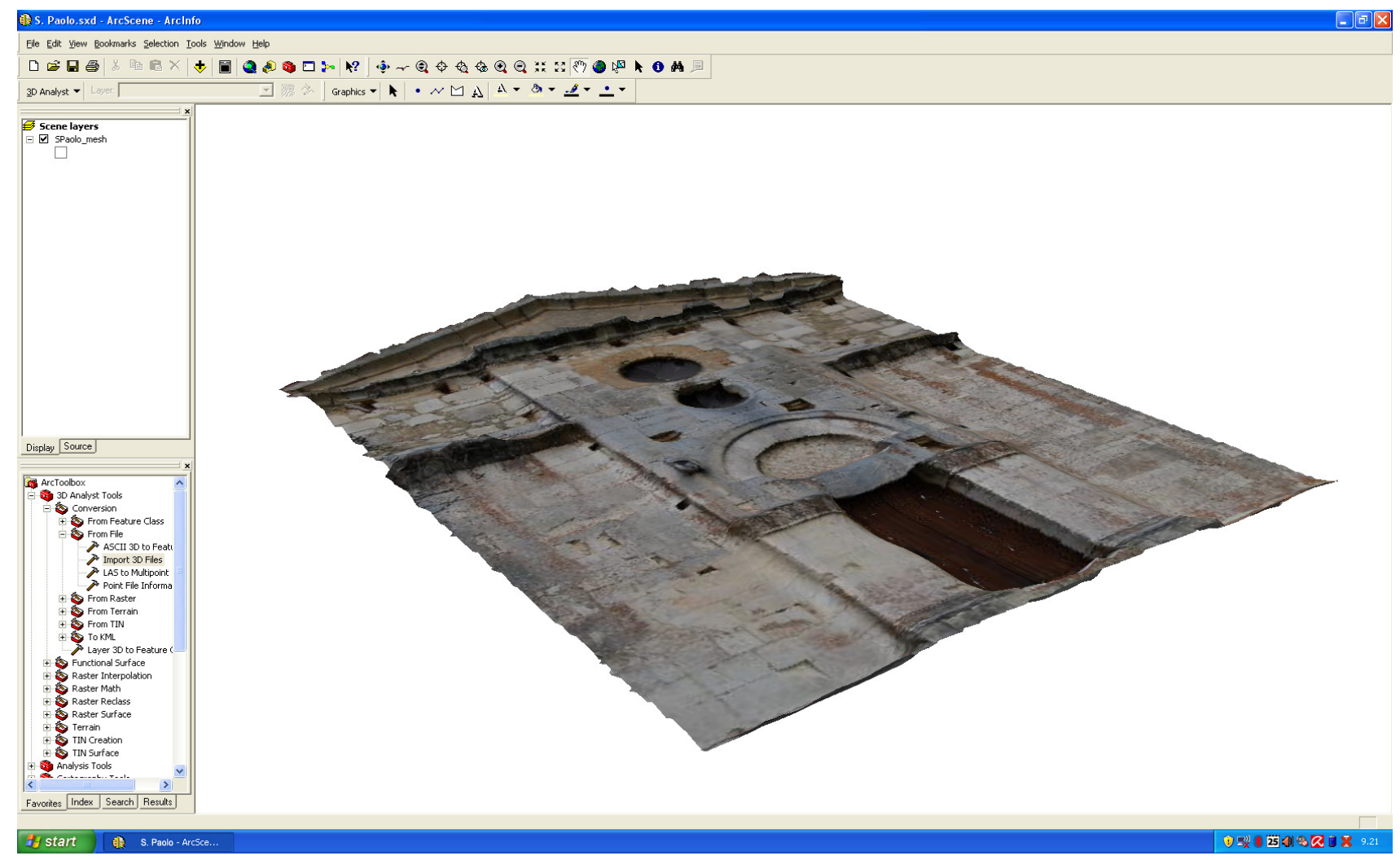

Picture 6-Textured mesh surface of S. Paolo facade imported in GIS environment. 
relation to not predictable interventions that have to be defined during the works.

\section{REFERENCES}

Brusaporci, S., (editor), 2010. Sistemi informativi integrati per la tutela, la conservazione e la valorizzazione del patrimonio architettonico e urbano, Gangemi, Roma, pp. 22-29.

Continenza, R., 2010. Il progetto del sistema informativo architettonico SIArch-Univaq. In: Brusaporci, S., (editor), Sistemi informativi integrati per la tutela, la conservazione e la valorizzazione del patrimonio architettonico e urbano, Gangemi, Roma, pp. 22-29.

Trizio, I., 2010. Il SIArch-Univaq della villa Correr-Dolfin di Porcia (PN) - Prospettive di un GIS 3D finalizzato alla catalogazione, al monitoraggio e alla salvaguardia del patrimonio storico architettonico. In: Brusaporci, S., (editor), Sistemi informativi integrati per la tutela, la conservazione e la valorizzazione del patrimonio architettonico e urbano, Gangemi, Roma, pp. 30-38.

Brusaporci, S., Trizio, I., 2010. Dal rilevamento integrato al SIArch 3D. In: Brusaporci, S., (editor), Sistemi informativi integrati per la tutela, la conservazione e la valorizzazione del patrimonio architettonico e urbano, Gangemi, Roma, pp. 39-42.

Trizio, I., 2009. Indagini Stratigrafiche e Sistemi Informativi Architettonici: il GIS della chiesa di S. Maria in Valle Porclaneta. Arqueología de la Arquitectura, n. 6, gennaio dicembre 2009, pp. 91-111.
Centofanti, M., Continenza, R., Ruggieri, G., Brusaporci, S.,Trizio, I., 2008. Il progetto del SIArch - Sistema Informativo per l'Architettura. Disegnare con..., 2, 2008; pp. 1-7.

Trizio, I., 2007. GIS-technologies and Cultural Heritage: stocktaking, documentation and managment. In: Rethinking Cultural Heritage. Experiences from Europe and Asia. Technische Universität Dresden, Dresden, pp. 75-91.

Clini, P., (editor), 2007, E-Arcom 07 Sistemi informativi per l'architettura. Alinea, Firenze.

Cundari, C., (editor), 2007. L'architettura di età aragonese nell'Italia centro meridionale. Verso la costituzione di un sistema informativo territoriale documentario e iconografico. Kappa, Roma.

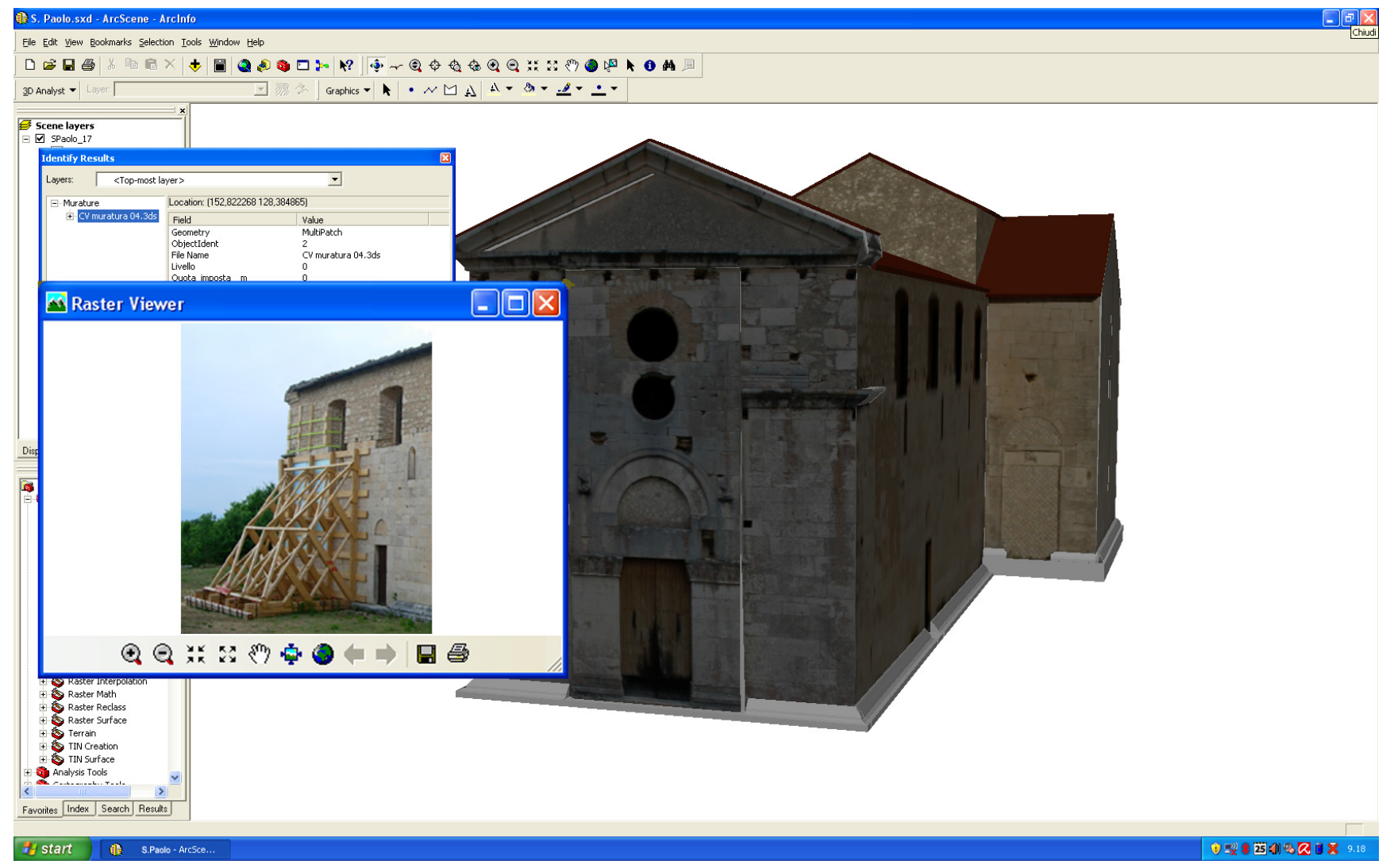

Picture 7 - Querying of photorealistic 3D model of S. Paolo church (AQ, Italy) in GIS environment 